\title{
Simplifying Excretory Urography in Children with Urinary Tract Infection
}

\author{
Lebrien Agustine Tamaela, Jahja Zacharia, Widhodho Titiet Karyomanggolo
}

\begin{abstract}
Abstrak
Infeksi saluran kemih (ISK) anak yang tidak ditanggulangi baik bisa berdampak fatal. Pencitraan uroradiologis, a.l. pielografi intravena (PIV), pemeriksaan terpilih untuk menggambarkan saluran kemih dengan lengkap, harus dilakukan. Tetapi dosis radiasi PIV tinggi. Tujuan penelitian ini ialah menilai efisiensi PIV tanpa kehilangan informasi diagnostik. Dilakukan studi observasi (memperoleh urogram dan kombinasi foto minimal yang lengkap menggambarkan komponen saluran kemih) dan studi perbandingan kemampuan diagnostik (menilai kemaimpuan pola PIV optimal, dibandingkan dengan PIV klasik). Tiap foto dari 100 seri PIV (foto polos perut, foto urogram menit ke 4, 8, 12 dan 30) periode Januari 1986 - April 1990, dinilai 3 penilai independen dalam hal kejelasan dan kemampuan deteksi kelainan. Yang dibandingkan adalah indeks efficacy uji diagnostik (sensitivitas, spesifisitas, nilai prediksi positif, nilai prediksi negatif, akurasi, rasio kemungkinan positif, rasio kemungkinan negatif). PIVklasik yang dinilai panel 2 pakar radiologi anak digunakan sebagai baku emas. Foto urogram menit ke 8 adalah foto tunggal paling lengkap untuk memvisualisasikan seluruh komponen PIV. Kombinasi foto polos dengan urogram menit ke 8 dengan atau tanpa urogram menit ke 4, adalah kombinasi PIV paling optimal. Kemampuan diagnostiknya ternyata setara dengan PIV klasik (pengurangan foto tidak mengurangi kemampuan deteksinya). Kesimpulan yang diperoleh ialah sebagian besar PIV dapat dihentikan setelah foto urogram menit ke 8. Pola PIV optimal adalah kombinasi foto polos dan urogram menit ke 8 dengan atau tanpa urogram menit ke 4. Ke 2 pola tersebut dapat digunakan sebagai alternatif pola pemeriksaan PIV rutin untuk pasien ISK anak.
\end{abstract}

\begin{abstract}
Failure to detect abnormalities in children with urinary tract infections may end up fatal. Excretory urography (EU) has been the examination of choice to visualize details of the urinary tract, but EU gives a relatively high radiation dose. The purpose of this study is to evaluate simplifying $E U$ without loosing its diagnostic efficacy. Observational and diagnostik tests comparison study has been done. Reevaluation of each film of 100 pediatric EU series in proven UTI cases examined from January 1986 - April 1990, by 3 independent investigators, describing visualization clarity and the presence of abnormality of the urinary tract. The 'gold standard' used was a consensus panel of 2 senior pediatric radiologists. The 8 minute urograms were found to be the most complete single film. As an examination, combination of plain photo of the abdomen and the 8 minute urogram with or without the 4 minute urograin, were the optimal 2 and 3 films EU procedures. By reducing exposure there was insignificant diagnostic efficacy lost. It is concluded that in most pediatric UTI cases, EU examination could be stopped after complete visualization of the urinary tract : after plain photo of the abdomen and 8 minute urogram with or without the 4 minute urogram. These could be recommended to be the minimal routine procedure.
\end{abstract}

Keywords : pediatric imaging, urinary tract infection, simplificarion, excretory urography, diagnostic tests, efficacy indexes

\section{INTRODUCTION}

Urinary tract infection (UTI) in infants and children is a common and significant childhood morbidity; many childhood UTI cases have some structural and/or functional urinary tract abnormalities, predisposing to recurrent and persistent UTI. Failure to detect underlying urinary tract anomalies and further mismanagement of complicated UTI, may end in chronic pyelonephritis and end-stage renal failure. $1,2,3,4,5$
The excretory urography (EU) has been the examination of choice to visualize both the details and the overview of the urinary tract. ${ }^{5,6}$ Unfortunately it gives a relatively high gonadal radiation dose which could increase the risk of malignancy induction and genetic damage. $^{8,9,10}$

Routine EU examination starts with a plain photo of the abdomen with a kidney ureter and bladder overview (KUB). This film usually detects radioopaque calculi, skeletal anomaly, calcification, and foreign 
objects and is used to evaluate the bowel preparation of the patient and as a control of the radiological technique. After IV injection of a contrast agent, some exposures are done to visualize the kidney, pelviocalyceal system, the ureter and the bladder, while the agent is being excreted. ${ }^{10,11,12}$

To get a complete visualization of these EU components, the experts have different ideas about the number and the sequence of the exposures. $6,10,11,12,13$ Since 1966 EU in our pediatric imaging sub division, has been performed in a routine procedure: 1 plain AP photo of the abdomen and $4 \mathrm{AP}$ urograms, each exposed at 4 (restricted to renal area), 8, 12, and 30 minutes. These exposures give overlapping visualization of the EU components, thus wasting $\mathrm{X}$-ray radiation.

The main purpose of the study was to find out whether EU could be simplified, without loosing its diagnostic efficacy. Simplified EU examinations will decrease radiation dose in pediatric patients (reducing pediatric radiation exposure), and on the other hand increases the possibility to perform more EU examina- tions for children needing this examination, especially in developing countries, with limited medical funding, man power (radiographers) and films.

\section{MATERIAL AND METHODS}

The study was conducted to evaluate 120 pediatric EU of UTI cases done in the Pediatric Imaging Sub Division of the Child Health Department, Medical School University of Indonesia/Cipto Mangunkusumo General Hospital, Jakarta, from January 1986 - April 1990. Two steps of the study consisted of observational studies and diagnostic tests comparison study (Fig.1). Eligible EU series had to have a proven culture of the mid-stream urine $\geq 100.000$ bacterial colony $/ \mathrm{ml}$ (proven UTI cases), and consisted of 5 photos: 1 plain AP photo of the abdomen (FO) and 4 AP urograms, done at 4 minutes, restricted to the renal area (F1), and at $8(\mathrm{~F} 2), 12(\mathrm{~F} 3)$ and 30 minutes (F4), giving a complete visualization of each of EU components. Any EU series with missing film and EU of umproven UTI were excluded.

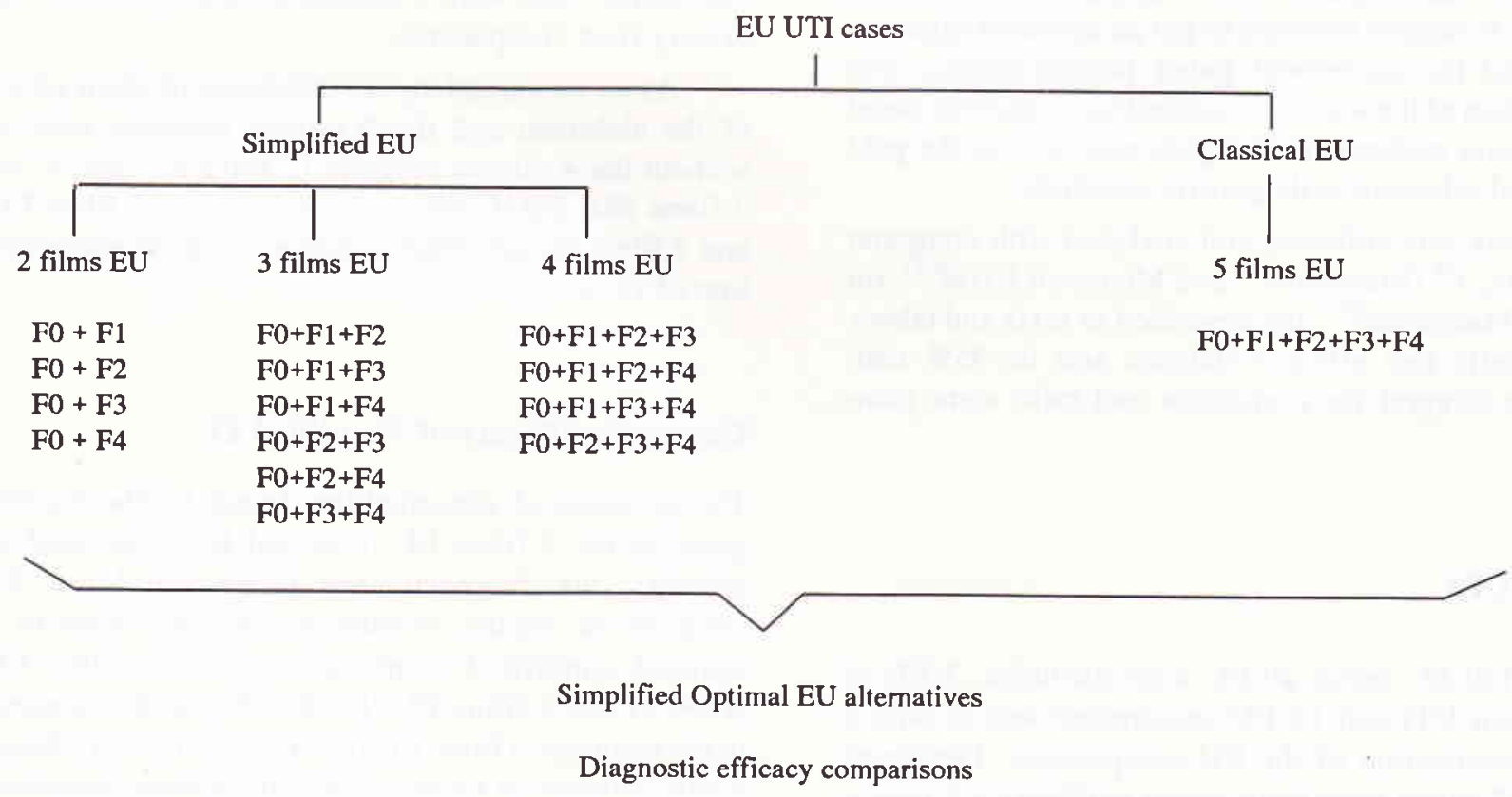

Figure 1. Study design. EU = excretory urography, $F O=$ plain photo of abdomen/kidney ureter and bladder, $F 1=4$ minute urogram, $F 2=8$ minute urogram, $F 3=12$ minute urogram, $F 4=30$ minute urogram 
Data collection was done by reevaluation of each UE component (visualization of the kidney, pelviocalyceal system, ureter and the bladder) on each film. Each film was evaluated independently with the usual sequence. Through a detailed criteria which had been discussed and tried out to several EU series before the study, radiological image of each component was transformed to categorical data. The evaluation of each component consisted of the visualization quality (classified as clear, unclear and others) and the abnormality shown (classified as normal, abnormal and others).

The first part of the study was to determine which single and minimal combination of EU films visualizes every EU component completely. And the second part was to determine whether there would be any information lost by simplifying EU. This part was done by comparing diagnostic efficacy indexes ${ }^{18}$ (sensitivity, specificity, positive and negative predictive value, accuracy, positive and negative likelihood ratio) of simplified optimal EU combinations and the diagnostic yield of a complete 5 films EU.

The whole data collection was done by 3 independent investigators ( 1 pediatric resident and 2 pediatric radiologists) with a blinded fashion twice (with $\geq 6$ months interval) to get an unbiased observation and the agreement index (kappa index). The evaluation of the whole EU series by a consensus panel of 2 senior pediatric radiologists was used as the gold standard (alternative diagnostic standard).

Data was collected and analysed with computer program, $4^{\text {th }}$ Dimension $^{(\mathrm{R})}$ and Microsoft Excel ${ }^{(\mathrm{R})}$, for Apple Macintosh ${ }^{(R)}$, and described as texts and tables. Diagnostic test efficacy indexes and its $95 \%$ confidence interval for proportion and ratio were compared.

\section{RESULTS}

From 120 EU series 20 EU were excluded, 5 EU of unproven UTI and $15 \mathrm{EU}$ uncomplete sets or with a bad visualization of the EU components. Twelve of these 15 series were from young children ( $\leq 5$ years). On 13 of these series, there was much bowel gas obscuring visualization of EU components that grew worse in later urograms/exposures. Two series were not clear because of inadequate radiographical technique. Most eligible EU series (58\%) were from $\leq 5$ years old children (Table 1 ), as $52,8 \%$ of UTI cases (ICD No. 599.0) in our outpatient clinic were young children.
Table 1. Age and sex distribution of pediatric UTI cases with satisfactory EU examinations

\begin{tabular}{|c|c|c|c|}
\hline \multirow{2}{*}{$\begin{array}{l}\text { Age } \\
(\mathrm{yr})\end{array}$} & \multicolumn{2}{|c|}{ Sex } & \multirow[t]{2}{*}{ Total } \\
\hline & Male & Female & \\
\hline $0-1$ & 6 & 6 & 12 \\
\hline $1-5$ & 20 & 26 & 46 \\
\hline $5-10$ & 19 & 13 & 32 \\
\hline $10-15$ & 7 & 3 & 10 \\
\hline $15-$ & 0 & 0 & 0 \\
\hline Tot a 1 & 52 & 48 & 100 \\
\hline
\end{tabular}

\section{Optimal Simplified EU}

The first step in the study was to identify which single film and which optimal simplified combination would give complete visualization of EU components. The study showed that 8 minute urograms (F2), followed by 12 and 30 minute urograms (F3 and F4) were the best single films with a complete visualization of the urinary tract components.

As an examination, combinations of plain photo of the abdomen and the 8 minute urogram with or without the 4 minute urogram ( 2 films EU: F0+F2 or 3 films $\mathrm{EU}: \mathrm{FO}+\mathrm{F} 1+\mathrm{F} 2$ ), are the optimal 2 films $\mathrm{EU}$ and 3 films EU procedures with a complete visualization of EU components (Table 2).

\section{Diagnostic Efficacy of Simplified EU}

The presence of abnormalities found by the experts panel in the 5 films EU (classical EU) was used to calculate the diagnostic test efficacy indexes. To simplify the results, evaluation was only done to 2 optimal simplified combinations, i.e. 2 films EU $(\mathrm{F} 0+\mathrm{F} 2)$ and 3 films $\mathrm{EU}(\mathrm{F} 0+\mathrm{F} 1+\mathrm{F} 2)$, and compared to the complete 5 films EU $(\mathrm{F} 0+\mathrm{F} 1+\mathrm{F} 2+\mathrm{F} 3+\mathrm{F} 4)$ : Diagnostic efficacy of these combinations were described in diagnostic test efficacy indexes and its $95 \%$ confidence interval (Table 3).

In EU series in which the simplified EU gave a complete visualization of the urinary tract, no diagnosis or abnormality were missed by either investigator. The efficacy indexes and its $95 \%$ confidence interval could be compared between those $3 \mathrm{EU}$ sequence (Table 3). 
Table 2. Combinations of EU films of pediatric UTI patients with clear visualization of EU components according to 3 investigators.

\begin{tabular}{|c|c|c|c|c|c|c|c|}
\hline \multirow{2}{*}{$\begin{array}{l}\text { Number } \\
\text { of films }\end{array}$} & \multirow{2}{*}{$\begin{array}{l}\text { Combination } \\
\text { of films }\end{array}$} & \multicolumn{2}{|c|}{ Investigator I } & \multicolumn{2}{|c|}{ Investigalor 3} & \multicolumn{2}{|c|}{ Investigator 3} \\
\hline & & $\mathbf{N}$ & $\%$ & $\mathbf{N}$ & $\%$ & $\mathbf{N}$ & \% \\
\hline \multirow[t]{4}{*}{2} & $0-1$ & 0 & $0.0 \%$ & 0 & $0.0 \%$ & 0 & $0.0 \%$ \\
\hline & $0-2$ & 36 & $48.0 \%$ & 46 & $54.8 \%$ & 32 & $43.8 \%$ \\
\hline & $0-3$ & 15 & $20.0 \%$ & 34 & $40.5 \%$ & 16 & $21.9 \%$ \\
\hline & $0-4$ & 7 & $9.3 \%$ & 32 & $38.1 \%$ & 8 & $11.0 \%$ \\
\hline \multirow[t]{6}{*}{3} & $0-1-2$ & 62 & $82.7 \%$ & 78 & $92.9 \%$ & 58 & $79.5 \%$ \\
\hline & $0-1-3$ & 53 & $70.7 \%$ & 77 & $91.7 \%$ & 57 & $78.1 \%$ \\
\hline & $0-1-4$ & 45 & $60.0 \%$ & 72 & $85.7 \%$ & 51 & $69.9 \%$ \\
\hline & $0-2-3$ & 44 & $58.7 \%$ & 70 & $83.3 \%$ & 42 & $57.5 \%$ \\
\hline & $0-2-4$ & 43 & $57.3 \%$ & 70 & $83.3 \%$ & 42 & $57.5 \%$ \\
\hline & $0-3-4$ & 25 & $33.3 \%$ & 58 & $69.0 \%$ & 21 & $28.8 \%$ \\
\hline \multirow[t]{4}{*}{4} & $0-1-2-3$ & 70 & $93.3 \%$ & 83 & $98.8 \%$ & 71 & $97.3 \%$ \\
\hline & $0-1-2-4$ & 70 & $93.3 \%$ & 84 & $100.0 \%$ & 72 & $98.6 \%$ \\
\hline & $0-1-3-4$ & 60 & $80.0 \%$ & 80 & $95.2 \%$ & 61 & $83.6 \%$ \\
\hline & $0-2-3-4$ & 50 & $66.7 \%$ & 71 & $84.5 \%$ & 44 & $60.3 \%$ \\
\hline 5 & $0-1-2-3-4$ & 75 & $100.0 \%$ & 84 & $100.0 \%$ & 73 & $100.0 \%$ \\
\hline
\end{tabular}

* The optimal combinations in each group were typed in hold letters

Table 3. Efficacy indexes of 3 alternative EU combinations hy 3 investigators

\begin{tabular}{|c|c|c|c|c|c|c|c|}
\hline \multirow{2}{*}{$\begin{array}{l}\text { Efficacy } \\
\text { indexes }\end{array}$} & \multirow{2}{*}{$\begin{array}{c}\text { No.of } \\
\text { EU films }\end{array}$} & \multicolumn{2}{|c|}{ Investigator 1} & \multicolumn{2}{|c|}{ Investigator 2} & \multicolumn{2}{|c|}{ Investigator 3} \\
\hline & & $\mathrm{P}$ & 95\% c.i & $\mathbf{P}$ & $95 \% \quad$ c.i. & $P$ & $95 \%$ c.i. \\
\hline \multirow[t]{3}{*}{ SE } & 2 films & 0.68 & $0.46-0.85$ & 0.68 & $0.46-0.85$ & 0.63 & $0.41-0.81$ \\
\hline & 3 films & 0.74 & $0.51-0.88$ & 0.68 & $0.46-0.85$ & 0.63 & $0.41-0.81$ \\
\hline & 5 films & 0.74 & $0.51-0.88$ & 0.68 & $0.46-0.85$ & 0.68 & $0.46-0.85$ \\
\hline \multirow[t]{3}{*}{$\mathrm{Sp}$} & 2 films & 0.93 & $0.85-0.97$ & 0.99 & $0.93-1.00$ & 0.98 & $0.91-0.99$ \\
\hline & 3 films & 0.93 & $0.85-0.97$ & 0.99 & $0.93-1.00$ & 0.98 & $0.91-0.99$ \\
\hline & 5 films & 0.91 & $0.83-0.96$ & 0.99 & $0.93-1.00$ & 0.96 & $0.90-0.99$ \\
\hline \multirow[t]{3}{*}{ PPV } & 2 fillms & 0.68 & $0.47-0.84$ & 0.93 & $0.69-0.99$ & 0.86 & $0.60-0.96$ \\
\hline & 3 films & 0.70 & $0.49-0.85$ & 0.93 & $0.69-0.99$ & 0.86 & $0.60-0.96$ \\
\hline & 5 films & 0.67 & $0.45-0.83$ & 0.93 & $0.69-0.99$ & 0.81 & $0.55-0.94$ \\
\hline \multirow[t]{3}{*}{ NPV } & 2 films & 0.93 & $0.85-0.97$ & 0.93 & $0.86-0.97$ & 0.92 & $0.84-0.96$ \\
\hline & 3 films & 0.94 & $0.86-0.97$ & 0.93 & $0.86-0.97$ & 0.92 & $0.84-0.96$ \\
\hline & 5 films & 0.94 & $0.86-0.97$ & 0.93 & $0.86-0.97$ & 0.93 & $0.85-0.97$ \\
\hline \multirow[t]{3}{*}{ A } & 2 films & 0.88 & $0.80-0.93$ & 0.93 & $0.86-0.97$ & 0.88 & $0.80-0.93$ \\
\hline & 3 films & 0.89 & $0.81-0.94$ & 0.93 & $0.86-0.97$ & 0.88 & $0.80-0.93$ \\
\hline & 5 films & 0.88 & $0.80-0.93$ & 0.93 & $0.86-0.97$ & 0.88 & $0.80-0.93$ \\
\hline \multirow[t]{3}{*}{ LR+ } & 2 films & 9.24 & $6.76-12.61$ & 55.42 & $40.79-75.29$ & 25.58 & $18.11 \cdot 36.12$ \\
\hline & 3 films & 9.95 & $7.55-13.10$ & 55.42 & $40.79-75.29$ & 25.58 & $18.11-36.12$ \\
\hline & 5 films & 8.53 & $6.46-12.61$ & 55.42 & $40.79-75.29$ & 18.47 & $13.57-25.15$ \\
\hline \multirow[t]{3}{*}{ LR- } & 2 films & 0.34 & $0.17-0.67$ & 0.32 & $0.16-0.62$ & 0.38 & $0.21-0.69$ \\
\hline & 3 films & 0.28 & $0.13-0.61$ & 0.32 & $0.16-0.62$ & 0.38 & $0.21-0.69$ \\
\hline & 5 films & 0.29 & $0.13-0.62$ & 0.32 & $0.16-0.62$ & 0.38 & $0.17-0.64$ \\
\hline
\end{tabular}

2 films $E U=K U B$ and $8 \mathrm{~min}$, urogram

3 films EU $=\mathrm{KUB}, 4^{\circ}$ urogram and $8^{\circ}$ urogram

5 films EU $=\mathrm{KUB}, 4^{\circ}$ urorgram, $8^{\circ}$ urogram, $12^{\circ}$ urogram and $30^{\circ}$ urogram

Efficacy = Sensitivity (Se), Specificity (Sp), Positive Predictive Value (PPV),

Indexes Negative Predictive Value (NPV), Accuracy (A), Likelihood Ratio+ (LR+) and Likelihood Ratio- (LR-); shown in calculated value (P) and its $95 \%$ conlidence interval (95\% c.i.) 


\section{DISCCUSSIONS}

Although in the literature UTI in children is often reported as the second most common infection in childhood $^{2}$ and EU is still suggested in every child suffering from UTI, ${ }^{4}$ yet in $\pm 41 / 2$ years study period there were only 120 EU series found with that indication. The explanation might be the fact that UTI in infants and children are often asymptomatic and underdiagnosed, not only clinically but also microbiologically and radiographically due to financial restrictions. And for this reason, we used all EU series that had been done during those $41 / 2$ years. We have to accept that the study sample was not the very representative of the target population, and we could not perform 'on the spot evaluation' of each film like in prospective studies. However we designed the study as natural as possible, by reading every film in the usual 'clinical sequence'.

The data collection, though from old EU series, were done through a detailed, 2 times and blinded reevaluation of every film, not influenced by the previous/excisting expertise (primary data). To increase the precision and accuracy of the study, we designed a standardized strict evaluation criteria of each EU component, to transform radiological image to nominal data. This criteria was tried out and discussed prior to the study to ensure visual perception agreement, which is very crucial in diagnostic radiological studies.

More than one investigator was meant to get the idea that results of this simplifying procedure were not influenced by the investigator's knowledge and experience. The multi observers' diagnostic capabilities were not meant to be compared, but to show the insignificant differences between the efficacy indexes of 2 simplified EU and the classical EU by one particular investigator.

Some previous investigators on this matter selected certain film(s) and evaluate its efficacy against the complete set. ${ }^{19,20,21,22}$ In this study a certain urogram was not chosen, weither a proposed hypothesis made to avoid film selection bias. The evaluation of the urogram was also stressed to be done in the usual sequence, with no backwards evaluation.

Transformation of radiological image, a blending of black-grey-white spectrum, to categorigal data will certainly be affected by the intraobserver and interobserver perception. To measure this factor, evaluation was done twice to get the reproducibility index (Table 4). The interevaluation period was more than 6 months to get a real blinded second evaluation, that was used in the analysis. The result showed that intraobserver reproducibility was good, ${ }^{18}$ showing the reliability of further analysis.
Table 4. Intra and interobserver agreement

\begin{tabular}{lcccc}
\hline Agreement & investigator & K & SE & Reproducibility \\
\hline Intraohersever & $1-1$ & 0,69 & 0,09 & good \\
& $2-2$ & 0,72 & 0,09 & $\begin{array}{c}\text { good } \\
\text { good }\end{array}$ \\
& $3-3$ & 0,67 & 0,14 & \\
Interobserver & $1-2$ & 0,48 & 0,12 & moderate \\
& $2-3$ & 0,37 & 0,14 & fair \\
& $1-3$ & 0,37 & 0,13 & fair \\
\hline
\end{tabular}

$\mathrm{K}=$ kappa index

$\mathrm{SE}=$ standard error

Reproducibility according to Landis and Koch modified by Altman ${ }^{18}$

To avoid 'measurement bias', no clinical data were disclosed, like fever as an important symptom related to the presence of urinary tract abnormality or ballotement in hydronephrosis cases. The evaluation by the 2 pediatric radiologists experts panel to reach a consensus was also done last. The results of this evaluation were considered as the truth (expert validity), functioning as the alternative diagnostic standard. In the ideal utopic setting, the gold standard of urinary tract abnormality should be the result of a complete uroradiological investigation, ${ }^{23}$ which should not be influenced by the result of EU itself. ${ }^{18}$

To make a simple $2 \times 2$ diagnostic test table, we simplify the evaluation of abnormality to a dichotomy (normal and abnormal) by classifying both the "normal" and "others" classification as "normal". This was considered as one category because both do not imply special treatment. And disregarding the EU result, most UTI in young children still need other means of uroradiological investigations as indicated, like the ultrasound examination and/or mictiocystourethrography. ${ }^{4,5,12,23}$

\section{Optimal urogram and EU combinations}

In EU series with a complete visualization of the urinary tract components, the combination of plain film +8 minute urogram ( 2 film EU) and the combination of plain film +4 minute urogram +8 minute urogram already have shown $43.8-54.8 \%$ and $79.5-92.9 \%$ respectively of complete visualization of the components (Table 2).

The diagnostic ability of simplified optimal EU procedures $(2$ and 3 films EU, those with minimal number of films but with a good percentage of complete visualization of the components) compared to the classical EU, showed that the differences between the efficacy indexes were insignificant (Table 3). In other words adding further exposures we would not give 
any extra diagnostic information. This result conformed the statement of some experts, that after the second exposed urogram no further exposure is needed. ${ }^{10,1} 1,12,15,16,17$

Simplified 2 film EU procedure (plain film +8 minute urogram) needed further exposures if the 8 minute urogram did not show the urinary tract components completely. In this study there was 1 abnormal case undetected by investigator 1 on the 2 film EU because the 8 minute urogram was blurred (the child moved during exposure), and another case by investigator 3 because the pelviocalyceal system was not clear yet. So 'diagnostic information loss' would not have happened, had the simplified EU procedures already visualized the urinary tract completely. This findings also conformed previous reports. Lähde et al. reported that plain film and a 10 minute uro-gram were enough in pediatric UTI cases. There were no management changes by simplifying the EU. ${ }^{20}$ Schey et al. reported that one 8 minute urogram either detected or excluded abnormality in most cases. ${ }^{22}$ The accuracy $(83.2 \%)$, sensitivity $(56 \%)$ and specificity $(91.3 \%)$ of one film ( 5 minute urogram) was also reported by Leonidas et al. ${ }^{21}$ Only in doubtful cases or imperfect films, they suggested to make further urograms. ${ }^{21,22,23}$ These reports reemphasized the importance of a radiologists presence in the simplified procedure to determine the necessity of any further exposure. ${ }^{10,11}$

Although the principle of minimal exposure in pediatric imaging is stressed by many centers, there is no one globally accepted film sequencing. Some conservative experts still defended the multi exposure (Table 5). McClennan stated that reducing the procedure had not proven efficacious, and these shortened urograms did not provide an acceptable level of diagnostic confidence. ${ }^{14}$ But from this study, the above reports, and the recommendation of the WHO expert committee. ${ }^{14}$ But from this study, the above reports, and the recommendation of the WHO expert committe, ${ }^{24}$ we should consider the idea of simplifying EU as a rational approach in uroradiologic investigations and that we should proceed with a prospective study performing these 2 or 3 films EU procedure for UTI cases in children.

If in the clinical setting EU can be performed in the 2 film EU procedure. If the 2 film EU has not shown the lower urinary tract, we still can make further exposure(s). In case the 8 minute urogram is too late to catch a clear nephrogram ( \pm pelviocalyceal system), we still can give another contrast injection 15,19 and make an earlier urogram, e.g. the 4 minute urogram. But because any added contrast agent injection is considered adding child's discomfort and risk plus some extra expenses, the 3 film EU procedure could be considered to be the optimal simplified EU too.

Tahle 5. Minimal routine exposure in pediatric EU according to some pediatric radiology centers/experts.

\begin{tabular}{|c|c|c|}
\hline No. of film & Exposure & Experts \\
\hline 2 films & $\begin{array}{l}\text { KUB } \\
6^{\circ} \text { AP urogram }\end{array}$ & Dunbar \& Nogardy, 1972 \\
\hline \multirow[t]{6}{*}{3 films } & $\begin{array}{l}\text { KUB } \\
\text { 6.AP urogram } \\
20^{\circ} \text { AP urogram }\end{array}$ & Emmett, 1964 \\
\hline & $\begin{array}{l}\text { KUB } \\
3^{\prime}-5^{\circ} \text { renal urogram } \\
10^{\circ} \text { AP urogram }\end{array}$ & Hartman \& Hattery, 1976 \\
\hline & $\begin{array}{l}\text { KUB } \\
1^{\prime} \text { renal urogram } \\
10^{\circ} \mathrm{AP} \text { urogram }\end{array}$ & Kirks, 1984 \\
\hline & $\begin{array}{l}\text { KUB } \\
30^{\prime \prime} \text { renal urogram } \\
10^{\circ} \text { AP urogram }\end{array}$ & Hilton, 1984 \\
\hline & $\begin{array}{l}\text { KUB } \\
4^{\circ}-5^{\circ} \text { renal urogram } \\
15^{\circ}-20^{\circ} \text { AP urogram }\end{array}$ & Gordon, 1988 \\
\hline & $\begin{array}{l}\text { KUB } \\
2^{\prime} \text { renal urogram } \\
7 \cdot \text { AP urogram }\end{array}$ & Dunbar, 1990 \\
\hline 4 films & $\begin{array}{l}\text { KUB } \\
3^{\circ} \text { renal urograin } \\
12^{\circ} \text { renal urogram } \\
\text { ]20 }^{\circ} \text { AP urogram }\end{array}$ & Smellie \& Normand, 1976 \\
\hline \multirow[t]{2}{*}{5 films } & $\begin{array}{l}\text { KUB } \\
4^{\circ} \text { renal urogram } \\
8^{\circ} \text {. } \text { AP urogram }^{\circ} \\
12^{\circ} \text { AP urogram } \\
30^{\circ} \text { AP urogram }\end{array}$ & $\begin{array}{l}\text { Tamaela et al, } 1989 \\
\text { (since 1966) }\end{array}$ \\
\hline & $\begin{array}{l}\text { KUB } \\
0^{\circ} \text { renal urogram } \\
3^{\circ}-5^{\prime} \text { renal urogram } \\
15^{\circ} \text { AP urogram } \\
15^{\circ} \text { lateral urogram }\end{array}$ & Aaronson \& Cremin, 1984 \\
\hline 6 films & $\begin{array}{l}\text { KUB } \\
1^{\circ} \text { renal urogram } \\
5^{\circ} \text { AP urogram } \\
10^{\circ} \text { AP urogram } \\
10^{\circ} \text { right oblique urogram } \\
10^{\circ} \text { left oblique urogram }\end{array}$ & Poznanski, 1976 \\
\hline 7 filıns & $\begin{array}{l}\text { KUB } \\
1^{\circ} \text { renal urogram } \\
4^{\circ}-5^{\circ} \text { renal urogram } \\
8^{\circ}-10^{\circ} \text { compressed AP urogr } \\
10^{\circ}-15^{\circ} \text { right oblique urogra } \\
10^{\circ}-15^{\circ} \text { left oblique urogram } \\
\text { post compression AP urogra }\end{array}$ & $\begin{array}{l}\text { gram } \\
\mathrm{m} \\
\mathrm{am}\end{array}$ \\
\hline
\end{tabular}

KUB = kidney ureter bladder overview; $\mathrm{AP}=$ anterior-posterior; $\mathrm{AP}=$ anterior-posterior; $\mathrm{PA}=$ posterior-anterior 


\section{Psychological approach in EU examination for pediatric patients}

In 13 of 15 EU series excluded from this study, much air in the bowel obscured the visualization of urinary tract components, especially in later urograms. An adequate bowel preparation can be ruined by this aerophagia, very possibly caused by excessive crying. And because for children excretory urography is considered as one of the most disliked examinations (starting with an injection in our department the procedure takes at least 30 minutes), the approach before and while undergoing this procedure should be improved. To uncooperative young children, immobilization restraint is also needed. Failure to do so will end up in improper/uninterpretable and blurred EU series. Simplified shorter EU procedure reduces the child's discomfort and hopefully will reduce the crying and its hindering impact on the visualization of urinary tract components.

\section{The impacts of EU simplification}

Simplification of EU procedure ( 2 or 3 films EU reduces the radiation dose, especially to the gonads, and theoritically reduces the examination cost. If the average gonadal radiation dose for boys is $42 \mathrm{mrad}$ and for girls 420 mrad per examination ${ }^{25}$ and if at least $50 \%$ EU examinations could be ended after 3 exposures, like in this study, there would be an average gonadal reduction of $\pm 60 \mathrm{mrad} /$ patient. The imaginary radiation reduction calculations for the whole population in this study are as follows: 58 (boys) $\times 50 \%$ (more than half could be simplified) $\times 60 \%$ ( 3 films compared to 5 films) x 42 mrad plus 42 (girls) x 50\% x $60 \%$ × 420 $\mathrm{mrad}=6,022.8 \mathrm{mrad} / 100$ patients. If the cost of 3 films $\mathrm{EU}$ is $60 \%$ of the cost of classical EU for a third class patient (Rp. 37,500,-), with similar calculations, there would be an imaginary reduction of cost of Rp. 7,500,/examination (50\% x $40 \%$ x Rp. $37,500,-)$.

Simplification of this examination means also cutting the time spent, thus increasing the possibility to improve the psychological approach to word children by the radiographers, as well as saving some life time of the radiologic equipment. With this simplified procedure more examinations could be arranged in the same length of time, with the same diagnostic facility, man power and film stock.

\section{CONCLUSIONS}

In most pediatric UTI cases, EU examination could be stopped after complete visualization of the urinary tract, i.e., after plain photo of the abdomen and 8 minute urogram with or without the 4 minute urogram. The diagnostic efficacy indexes of these simplified EU procedures were not increased by adding other urogram(s). These 2 or 3 films EU could be recommended to be the minimal routine procedure in pediatric patients suffering from UTI.

\section{ACKNOWLEDGEMENTS}

We are grateful to Drs. Bambang Madiyono and Sudigdo Sastroasmoro for their contributing advice on the statistical aspects and to Mr. Heri Sukisno for preparing appropriate computer software.

\section{APPENDIX}

\section{Confidence interval calculations}

Confidence intervals of proportion diagnostic radiology efficacy indexes (sensitivity, specificity, accuracy, positive and negative predictive value) were calculated by ${ }^{1}$

$$
\begin{aligned}
& \text { c.i. }=\frac{2 p+\theta^{2} \pm \theta \sqrt{\theta^{2}+4 p(1-p)}}{2+2 \theta^{2}} \\
& \begin{aligned}
& \text { c.i. }= \text { confidence interval } \\
& p \quad \text { proportion } \\
&= Z_{\alpha / 2} / \sqrt{N} \\
& Z_{\alpha / 2}= \text { normal standard deviation for two-tailed } \alpha ; \\
& \text { for } 95 \% \text { confidence level in this study, } \\
& Z_{\alpha}=1,96
\end{aligned} \\
& N=\text { sampel size }
\end{aligned}
$$

Confidence intervals for the likelihood ratios were calculated by ${ }^{2}$

\footnotetext{
${ }^{1}$ Berry CC. A tutorial on confidence intervals for proportions in diagnostic radiology. Am J Roentg 1990; 154: 477-480.

2 Morris JA, Gardner MJ. Calculating confidence intervals for relative risks, odds ratios, and standardised ratios and rates. In: Gardner, Altman, editors, Statistics with confidence. London: British Medical Journal, 1989: 50-52.
} 


$$
\begin{aligned}
\text { c.i. }= & e^{W}-e^{X} \\
e & =\text { exponential function for antilog, transformation } \\
W= & \log _{e} L R-Z_{\alpha} \times S E \log _{e} L R \\
X= & \log _{e} L R+Z_{\alpha} \times S E \log _{e} L R \\
\log _{e}= & \text { normal logaritm of the basic constant number } \\
& \text { e }(e=2,718281)
\end{aligned}
$$

For likelihood ratio $+(L R+)$ SE $\log _{e} \mathrm{LR}+=$

$$
=\sqrt{\frac{1}{a}-\frac{1}{a+c}+\frac{1}{b}-\frac{1}{b+d}}
$$

For likelihood ratio - (LR-) SE $\log _{\mathrm{e}}$ LR- =

$$
=\sqrt{\frac{1}{c}-\frac{1}{a+c}+\frac{1}{d}-\frac{1}{b+d}}
$$

\section{REFERENCES}

1. Smellie JM, Normand ICS. Urinary infections in children. Post- grad med J 1985; 61: 895-905.

2. Brouhard BH, Travis LB. Infections of the urinary tract. In: Rudolph, Hoffman, Pediatrics. $18^{\text {th }}$ ed. Norwalk: Appleton \& Lange, 1987; 1197-202.

3. Tambunan T. Penanggulangan pielonefritis kronik pada anak. Dalam : Pendidikan Tambahan Berkala Ilmu Kesehatan Anak: Penanggulangan penyakit ginjal kronik pada anak; Jakarta 1 Juni 1983; 23-31.

4. Alatas H. Penanggulangan infeksi traktus urinarius pada anak. Maj Kedok Indones 1983; 33: 117-21.

5. Lebowitz RL, Mandell J. Urinary tract infection in children: putting radiology in its place. Radiology 1987; 165: 1-9.

6. Friedenberg RM, Dunbar JS. Excretory urography. In Pollack, editor, Clinical urography. Philadelphia: Saunders, $1990 ; 101$.

7. Badan Tenaga Atom Nasional. Pedoman proteksi radiasi di rumah sakit dan tempat praktek umum lainnya. Jakarta: BATAN, 1985.

8. Pohlit W. Radiation risk in the pediatrc age group. Institut für Biophysik der Universität Frankfurt. In press.

9. Walker JS. The controversy over radiation safety. A historical overview. J Am med Ass 1989; 262: 664-8.
10. Emmett JL, editor. Methods in urographic diagnosis. In: Clinical urography. $2^{\text {nd }}$ ed. Philadelphia: Saunders, 1964; 1-36.

11. Hartman GW, Hattery RR. Uroradiology: procedures and anatomy. In: Kelalis, King, Belman, Clinical pediatric urology: Philadelphia: Saunder, 1964; 15-37.

12. Hilton $S$. The child with a urinary tract infection. In Hilton, Edwards, Hilton, editors, Practical pediatric radiology, Philadelphia: Saunders, 1964: 15-37.

13. Aaronson IA, Cremin BJ, editors. Imaging techniques. In: Clinical paediatric uroradiology. Edinburgh: Churchill Livingstone, 1984; 18-22.

14. McClennan BL. Urography-anatomy and technique. In: Pollack, editor, Clinical urography. Philadelphia: Saunders, 1988; $1166-7$.

15. Dunbar JS. Excretory urography in infants and children. In: Pollack, editor, Clinical urography. Philadelphia: Saunders, 1990; 207.

16. Gordon I. Urinary tract in paediatrics: the role of diagnostic imaging. Br J Radiol 1990; 63: 507-11.

17. Kirks DR, editor. Genitourinary tract. In: Practical pediatric imaging. Diagnostic radiology of infants and children. Boston/Toronto: Little Brown, 1984; 676-743.

18. Altman DG, editor. Some common problems in medical research. In: Practical statistics for medical research. London: Chapman and Hall, 1991: 396-439.

19. Hilman B, Abrams HL, Hessel SJ, Herbert S, Benazzi RB, Gerson DE. Simplifying radiological examinations. The urogram as a model. Lancet 1979; i: 1068-71.

20. Lähde S, Standerskjöd-Nordenstam C-G, Suoranta H, Phytinen J. Two-picture urography in urinary tract infections. J Urol 1981; 125: 820-1.

21. Leonidas JC, Schwartz R, Schwartz AM, Mc Cauley RGK, Darling DB. The one-film urogram in urinary tract infection in children. Am J Roentg 1983;141:61-4.

22. Schey WL, Shkolnick A, White H, Finder C. Eight-minute excretory urographic film: once is enough. Urology 1981; 18: $515-8$.

23. Nogardy MB. Diagnostic imaging of the urinary system in infants and children. In: Behrman, Vaughan, Nelson, editors, Textbook of Pediatrics. $12^{\text {th }}$ ed. Philadelphia: Saunders, 1983; 1314-8.

24. WHO Study Group. Rational use of diagnostic imaging in paediatrics. WHO Technical Report Series, 1987; 757: 4951.

25. Troupin $\mathrm{R}$, terjemahan. Pemaparan radiasi pada radiologi diagnostik dalam klinik. Jakarta: ECG, 1989; 5-7. 